\title{
KINESIOLOGY IN FUNCTION OF THE SKELETAL-MUSCLE DEFORMATION PREVENTION AT SCHOOL AGE
}

\author{
Associent Prof. Mitrichka Ks. Stardelova - PhD in Medicine FKK, Department of Kinesiology Anthropology, \\ Skopje, Macedonia \\ Associent Prof. Dimitrinka K. Conkova VTU, Veliko Tarnovo, Bulgaria \\ Dr.med. V. Krstevska Center for scoliosis and physiotherapy in Skopje, Macedonia \\ D-r.med. Nevenka Panovska Center for scoliosis and physiotherapy in Skopje, Macedonia \\ M PhD. Selim Alili freelancer cooperator, scoliosis and physiotherapy center, Skopje, Macedonia \\ Academician - DHK Prof. Dr.. Angel Dzhambazovski Center for scoliosis and physiotherapy, Skopje - \\ Macedonia
}

\begin{abstract}
The research is conducted on 1000 male respondents from the eighth grade all the way to the completion of their secondary education. The deviations of the foot and the spinal cord malformations as well as the bad body posture with chest deformities were mainly analyzed.The visual method was used for the registration of all the malformations that represent a deviation from a normal body posture. Analysis of orthopedic and aesthetic bodily disorders were carried out by the abovementioned authors on a thousand students from 15 to 19 years of age. Deviations were found in the normal form of foot $23.8 \%$, spinal cord deformities $20.5 \%$, and the bad body postures with chest deformities $16.3 \%$. The main reason for this situation are the hypokinesis, and in order to be solved it is recommended private and the state property centers for aesthetic and orthopedic kinesiology and physiotherapy to open.
\end{abstract}

Keywords: $\quad$ Kinesiology Medicine, Physiotherapy, Kinesiotherapy, diseases of nowadays, malformations.

\section{INTRODUCTION}

\section{Kineziology Medicine}

Physiotherapy and Kinesiotherapy are relevant in the presence of pandemics of diseases of nowadays, such as: skeletal deformities, cardiovascular, degenerative diseases, hormonal etc.. This results as a lower physical burden of children activities due to growth and development stage of their body-lately the orthopedic deformities are present with a very high percent. The analysis of different health checks within Balkan countries and Europe showed an increase of malformations among students. The reasons for this situation despite hypo kinesis are also the wrong diet, the long sitting in front of the TV Set, computers, improper seating, creating of wrong stereotyped posture models, as well as the switching the night-time with the day-time sleep.

The biggest problem for this situation are the densely populated urban areas where the physical activity is reduced to zero. If ever a man mentally used to perform $1 \%$ of his survival activities, and the rest he was shiftin through the personal physical effort and gravitate up to $100 \%$, the physical effort today in urbanized areas is reversed, so that the physical effort gravitates toward zero, and the intellectual up to $100 \%$. Such a condition of hypokinesia is one of the reasons for the huge percentage of skeletal-muscle malformations. 


\subsection{RESULTS AND DISCUSSION}

From our research it is shown that the percentage deviation from the normal development of the body of the child in the process of growth and development is very large. Having in mind that $23.8 \%$ of children have a deviation from normal physiological-morphological structure of the foot, with a lowered arch, called flat foot. We assume that that this situation arose due to lack of physical effort, rarely walking of children with barefoot. It is interesting to note that children who have flat feet usually have vertebral deformities, so that their percentage is $20.5 \%$, and many of them have deformities of the chest $16.3 \%$. General and the main reason for this situation are the hypokinesis and they result with the appearance of gained vertebral deformities known as: one-sided or two-sided distortions columna vertebralis, generally called skoliosi, meaning lateral curvature of the spine, then curved front-rear direction, known as lordosi and kifosi, also the false feet called planus pedis, and various deformities of the chest.

Similar results in a larger study by the Institute of Public Health of the Republic of Macedonia obtained data for alarming deterioration of backdeformations. Thus, the Institute for Healthcare Macedonia analyzed over 2000 students from primary, secondary and higher education, respectively in 1995 and the same population was examined in 2006. From the results in 2006 compared to the 1995, there has been a kifozite deterioration in $18.5 \%$, in skoliozite $26.9 \%$, lordozite between students and upper classes showed deterioration $86.2 \%$ comparatively speaking in terms of pre ten years ago today. Which results with a constant deterioration.

According to the National Institute of Public Health in Republic of Macedonia Research results (published on 12.02.2007 in the daily Newspaper "Vreme" p.2 entitled "Computers hunched the children"), are following:

1.0. Deformities among primary school students

1.1. Foot deformities $22.6 \%$

1.2. Spinal cord deformities $17.6 \%$

1.3. Bad body posture $17.3 \%$

2.0. Deformities among high school students

2.1. Bad posture $22.5 \%$

2.2. Foot deformities $17.6 \%$

2.3. Spinal cord deformities $15.9 \%$

The results are published in the percent of a thousand children.

\subsection{CONCLUSION}

Nowadays diseases, the skeletal deformities - cardiovascular and degenerative hormonal diseases, according to other studies, also follow our obtained results. These skeletal-muscle apparatus condition diseases are the nowadays diseases and are result of insufficient physical children and adults activity, a condition generally known as hypokinesia that genuine concerns and probably is confirmed as the main cause for the spinal cord deformities. Beside the hypokinesis, the lifestyle is also important, the nurture, the material conditions, the general quality of life etc.. The cause of the hormonal disorders, apoplexy, heart attacks, high blood pressure and other nowadays diseases are also already above mentioned factors.

Within a situation like this, the State University of Physical Education should present in front of the state authorities a special program for the prevention of the skeletal-muscle deformations, as well as the functionalmotor disabilities preventively to be stopped, i.e.by increasing of the number of hours of physical and health education at least three hours per week starting in first grade. To increase the teaching quality of aesthetic body shaping and to control the physical development of the students, to be followed by the teacher and to monitor the 
biological formation of the student together with the doctor, referring to children who have vertebral deformities to instructing them to the kinesiotherapy centers. The demand for the establishment of private offices - a cabinet for orthopedic and aesthetic kinesiology becomes greater. Creating preconditions for mass physical culture among the population, infrastructure as well as enrichment opportunities with sports facilities.Motivating and guiding graduated people for specializations for two semesters for orthopedic and aesthetic kinesiology, and the master's degree to perform the function of cocoordinating theory with practical knowledge and differential efforts to be put into operation needs of the kineziology -medical practice. The demand of larger state investment in these diseases prevention is the need and necessity of the 21 st century.

\section{REFERENCE}

1. Enoka. R. M.: "Osnovni kineziologii", Kiev, 2000 (Osnovi na kineziološkata teorija-humana kinetika).

2. Zavod za zdravstvena zaštita, Kompjuterite i rancite gi zgrbavija decata. Grupa avtori: "Vreme" 12.02.2007, Skopje.

3. Janev V.: "Intelekt i dejnost na sportista". Sporten intelekt, Sofija, 1997

4. Momirović, K., R, Medved., V. Horvat, Pavišić Medved., B.: Normativi kompleta antropometriskih varijabla školske omladine oba spola u doba od 12 do 18 godina, fizička kultura br. 9-10, Beograd, 1979 .

5. Naumovski A., S. Matovski, A. Xambazovski: "Komparirawe na biomotornata faktorska struktura kaj učenicite pred i posle treningot so različni sportovi”. Fizička kultura, Skopje, Tom 26, 1-2, str. 20-25, 1995.

6. Petrov, L.: Formirane i razvitie na Teorijata i praktikata na fizičeskoto vospitanie, glava 1. Teorija na fizičeskoto vospitanie, Veliko Trnovo, 2003..

7. Petrov N; Džambazovski A.; sorabotnici: "Proekcija za razvojot, inoviranjeto i transformiranjeto na sistemot na vospitanieto $i$ obrazovanieto vo Republika Makedonija". Redakcija na spisanieto, "Prosvetno delo", Skopje, 1994.
8. Popovski, D.: Sportovite vo voda, Univerzitet "Kiril i Metodij" Skopje, 1988.

9. Radovanović,: Uspeh studirawa i sportska aktivnost studenata. Fizička kultura, Beograd, 1974.

10. Stardelova Dž. M.: “Ontogenetskiot razvoj kaj učenicite od dvata pola od osnovnoto i srednoto obrazovanie vo Makedonija kako predikcija za selekcija vo sportot".Doktorska disertacija, Maj 2006, Skopje

11. Stardelova Dž.M.: Kineziološkite aktivnosti kako zadol'itelna potreba i nu’nost na novoto vreme, Ohrid, 2003.

12. Stardelova Dž.M.: Struktura na fizičkata kultura, struktura na kineziologijata, 17 i 19 Septemvri 2004, Ohrid.

13. Stardelova Dž.M.: Kineziološka medicina i kineziološka ortopedija. Ruse, 2004.

14. Stardelova Dž.M.: Kineziološko obrazovanie kako zadol itelna nu`nost na $21^{\text {ot }}$ vek. Varn, Oktomvri 2004.

15. Stardelova Dž.M.: Transformacija na fizička kultura od interdisciplinarna nauka vo samostojna nauka narečena Kineziologija. Belgrad, 12.12.2003.

16. Stardelova M. Dž ambazovski A., Panovska N.: Ergonomic standards for children. Naučna konferencija s me`dunarodno učastie. Fizičesko vzpitanie, sport, kineziterapija. Blagoevgrad 2009.

17. Stardelova Dž.M. Dž ambazovski A., Conkova D.: Antropometrično-motornite funkcionalnite sposobnosti na učenicitre od osnovnoto i srednoto obrazovanie. V. Trnovo, 2006.

18. Stardelova Dž.M., A. Dzambazovski, N. Panovska, V. Krstevska.: Značaj fizičkog obrazovawa za vaspitače strukovnih studija u funkciji prevencije kičmenih deformacija i bawsko - fizioterapeutskog turizma. Zbornik radova sa sestog simpozijuma "vaspitač u 21 veku". Aleksinac, 2011.

19. Džambazovski A.: "Kineziološka medicina", Skopje, 1990.

20. Džambazovski A.: "Teorija na fizičkata kultura". (voved vo kineziologijata). Skopje, 1998 i 2002g.

21. Džambazovski A., M. Stardelova, D. Kadinova - Conkova.: Antropometriskite - motornite i funkcionalnite sposobnosti na učenicite od osnovnoto i srednoto obrazovanie. Rusevski Univerzitet, Ruse, 2005.

22. Džambazovski A., M. Dž. Stardelova.: Specijalna kineziologija. Orginalen naučen doklad. Rusenski Univerzitet. Ruse, 2005.

23. Džambazovski A., Stardelova Dž.M., Džambazovski K., Spasovska K.: Primena terapije za grupu habitualne likasacije ramenog zgloba. Zbornik radova sa šestog simpozijuma "vaspitač u 21 veku". Aleksinac, 2011.

24. Džambazovski A., Stardelova M.: Our physiotherapy in curing of discus hernia. Jobileina 
naučna konferencija $\mathrm{s}$ me'dunarodno učastie. "Fizičeskoto vzpitanie i sport $\mathrm{v}$ obrazovatelnata sistema". Blagoevgrad, 2007.

25. Džambazovski A., Stardelova M., Krstevska $\mathrm{V} .:$ Našija opit $\mathrm{v}$ lečenieto na grbačnite deformacii. $\mathrm{Na}$ tr’estvenoto čestvanie i naučna konferencija pod patrona'a na rektora na NSA "V. Levski" prof. L. Dimitrov, 60 godini Kineziterapija v Bulgarija 2007.

26. Džambazovski A.: Kineziološka medicina sportska fizioterapija - hiropraktika - medicinska kineziterapija, Skopje, 2011.

27. Džambazovski A., Stardelova Dž.M.: Teorija na antropološkata kineziologija. Skopje, 2011. 